\title{
Green Economy and Economic Growth: Trends, Challenges and Opportunities for the EU
}

\author{
Adam Albekov ${ }^{1}$, Natalia Vovchenko ${ }^{2}$, Yevgeniya Medvedkina ${ }^{3}$, Taras \\ Medvedkin $^{4}$
}

\begin{abstract}
:
This paper substantiates the necessity for studying the complexity and ambiguousness of green economy principles', opportunities' and drivers' influence in a view of the need for maintaining the economic growth in the EU countries and comparing issues of sustainable development in Russian Federation according to the rules of green economy.

On the basis of foreign experience review and publications' analysis, the main dimensions of economic growth philosophy are proposed. These dimensions are related to preserving and expanding the peculiarities of economic growth, forming the post-industrial society with friendly attitude to environment, developing horizontal links and the opportunities of sustainable development.
\end{abstract}

The verification of hypothesis of the dense interconnection between 'green' economy efficiency indicators and achieving the economic growth in the framework of individual economic system as well as in human civilization in general is conducted with economicmathematical tools.

Keywords: green economy, green growth, economic development, EU trends.

\section{Acknowledgement:}

The publication was prepared within the framework of the implementation of the Basic Research Program of the Presidium of the Russian Academy of Sciences I.23 "Scientific foundations for the development of the Russian scientific and innovative complex in the context of global transformations" (state task of the SSC of RAS for 2018. Project No. AAAAA18-118011990280-4).

\footnotetext{
${ }^{l}$ Dr. Prof., Head of Logistics and Commerce Department, Rostov State University of Economics, Russia, Email: main@rsue.ru

${ }^{2}$ Dr. Prof., Prof. of Finance Department, Rostov State University of Economics, Russia,

Email:nauka@rsue.ru

${ }^{3}$ Dr. Prof., World Economy, Politics and Globalization Department, Rostov State University

of Economics, Russia, Email: yevgeniya.medvedkina@gmail.com

${ }^{4}$ Dr. Prof., World Economy, Politics and Globalization Department, Rostov State University

of Economics, Russia,Email: taras.medvedkin@gmail.com
} 


\section{Introduction}

Present recession being the feature of macroeconomic advancement of the EU countries, makes relevant the necessity of adjusting current tools of financialeconomic, industrial and social policy with simultaneous energizing of looking for new strategic directions and drivers of economic growth.

It is needed to be said that promoted by Organization for Economic Cooperation and Development (OECD) economic growth goals are the integral part of Sustainable Development Goals (SDGs) as a result of the Rio+20 United Nations Conference on Sustainable Development. Thus, on the one hand, three unresolved issues of record growth rate period of 1990th and 2000th, according the biennial OECD reports are declared to be poverty, unemployment and inequality since 2012 still unsolved up to nowadays. On the other, it should be said that the paradox between the rate of economic growth and it causes, structure and sources is actual. In other words, a fundamental question appears - where will it be the edge between the growth and ecological 'rent' or 'fee'?

The current issues are mentioned as the consequences of economic growth by Noble Prize-winning economists Paul Robin Krugman (Krugman, 2016) and Joseph Eugene Stiglitz (Stiglitz, 2015) who directly bring the matter of existential choice for human civilization into the context of evolutionary transformations. In other words, it is not about doubting the fairway of world economy, which is the necessity of resuming of economic dynamics and states' well-being, but about revealing and definition of new triggers being the new key issue shifting the traditional emphases of states' and global corporations' industrial policy.

On the other hand, in the Blueprint for a Green Economy (Pearce et al., 1989) the term green economy was first coined in a pioneering 1989 report for the Government of the United Kingdom by a group of leading environmental economists. The report was commissioned to advise the UK Government if there was a consensus definition to the term 'sustainable development' and the implications of sustainable development for the measurement of economic progress and the appraisal of projects and policies (i.e. "...sustainable development is development that meets the needs of the present without compromising the ability of future generations to meet their own needs...").

Therefore, the logic of current research contemplates the understanding of the latest challenges by sustainable development of economic systems with various taxonomic attributes influence the achieving of positive dynamics and key development indicators increasing in the framework of assumptions and limitations provided by the principles for the green economy.

\section{Research Hypothesis}


The authors of the presented scientific article tried to identify the possibility of existence and prospects for potential interaction between the points of economic growth of the EU countries and the principles of the green economy, the main guidelines for the implementation of the principles of which were outlined since the Millennium Development Goals (UN, 2015).

Presented in the very beginning of the XXI century goals provided an anchor for policy change and socially responsibility in the environmental economy. However, whilst addressing the needs of the bottom of the social and economic pyramid, these goals fell short of promoting development for all. That gap is now being filled by the Sustainable Development Goals (SDGs) to kick-start the 2030 Agenda for Sustainable Development. This Agenda and the SDGs offer an opportunity to reframe economic policy around the core elements of sustainability, lead very concretely by a focus on building and creating inclusive green economies in the clause of GDP growth.

The Global Green Economy Index, GGEI (Dual Citizen LLC, 2015) measures both the green economic performance of 80 countries and how experts assess that performance. The GGEI performance index uses quantitative and qualitative indicators to measure how well each country performs on four key dimensions: leadership \& climate change, efficiency sectors, markets and investment and the environment.

So, according to the presented facts it should be said that the EU countries on the one hand have an extraordinary possibility, empirical background and experience for the Pan-European ecological leap and on the other hand - they are the most suffered deep integrated social and economic system either on nation-state level or regional level in general.

Thus, the current paper presents the results of research in the sphere of defining balance between economic growth and principles of green economy, which take place all over the EU countries.

\section{Background and Rational}

There were a lot of excellent scholars in the last 50 years who had made the remarkable contributions to the green economy and sustainable development studies, economic growth and modernization studies, such as Talcott Parsons, Daniel Lerner, Walt W. Rostow, Samuel Huntington, etc., to the orthodox modernization theory; to the dependence theory; Immanuel Wallerstein, etc., to the world system analyze theory; Daniel Bell, Jean-Francois Lyotard, Ronald Inglehart, etc., to the postmodernization theory; Joseph Huber, Martin Janicke, etc., to ecological theory; Ulrich Beck, Anthony Giddens, etc., to the reflexive modernization theory; Edward A. Tiryakian and Wolfgang Zapf to the new or continual modernization theory; David Held, etc., to the globalization theory; Shmuel N. Eisenstadt, etc., to the 
multiple modernity's theory; and Chuanqi He, etc., to the second modernization theory and integrated modernization theory.

The current scientific approach is an interdisciplinary one, which deals with sustainable development, economic growth and modernization phenomena. They illuminate two basic tasks: (1) describing and explaining the frontier changes and international competition in the frames of limits of economic growth and (2) explaining and providing principles and methods of sustainable development and green economy.

\section{Methodological Approach}

The global and regional dynamics of restoring positive trends of development actualize the search for a compromise between achieving GDP growth as the resultant indicator of the dynamics by country and preserving environmentally acceptable, friendly conditions for expanded reproduction, their key characteristic being the implementation of the norms and principles of the green economy (Thalassinos and Pociovalisteanu, 2009; Thalassinos, 2007).

In the framework of current research, the economic and mathematical instruments of analysis were used for understanding of the dynamics in structure of the economy in the EU countries according to changes in basic sectors (agriculture, services and industry), economic growth rates in the framework of traditional models of economic development and modern imperatives of economic growth achievement within the 'beyond GDP' concept and the concept of a green economy in general.

An important factor being an objective condition for achieving economic growth in the present conditions of the world economy development is the symbiotic and international interaction of structural elements of economy structure, the valueadded sources, including the integration of the private and public sectors.

Thus, a complex field of scientific search is being formed in the framework of problems stated, namely: increasing the dynamics of GDP (economic growth), sustainable development (effective nature management) and applied country specific features of applying the norms and principles of the 'green' economy. This case catches the EU countries future between a rock and a hard place.

\section{Discussion}

The purpose of this analyze is to review some of the most prominent theories of economic development. These theories describe tools and strategies for making development of socio-economic system achievable. The current investigation starts with early views about the nature of economic prosperity and growth. Authors then review classical theories with four main clusters: linear stages of growth models; structural change models; international dependence models; and neoclassical 
counter-revolution models (Figure 1). Subsequently, contemporary theories of economic development, including new growth theory and theory of coordination failure, are reviewed (Pociovalisteanu and Thalassinos, 2008).

Figure 1. Theoretical basis of presented research

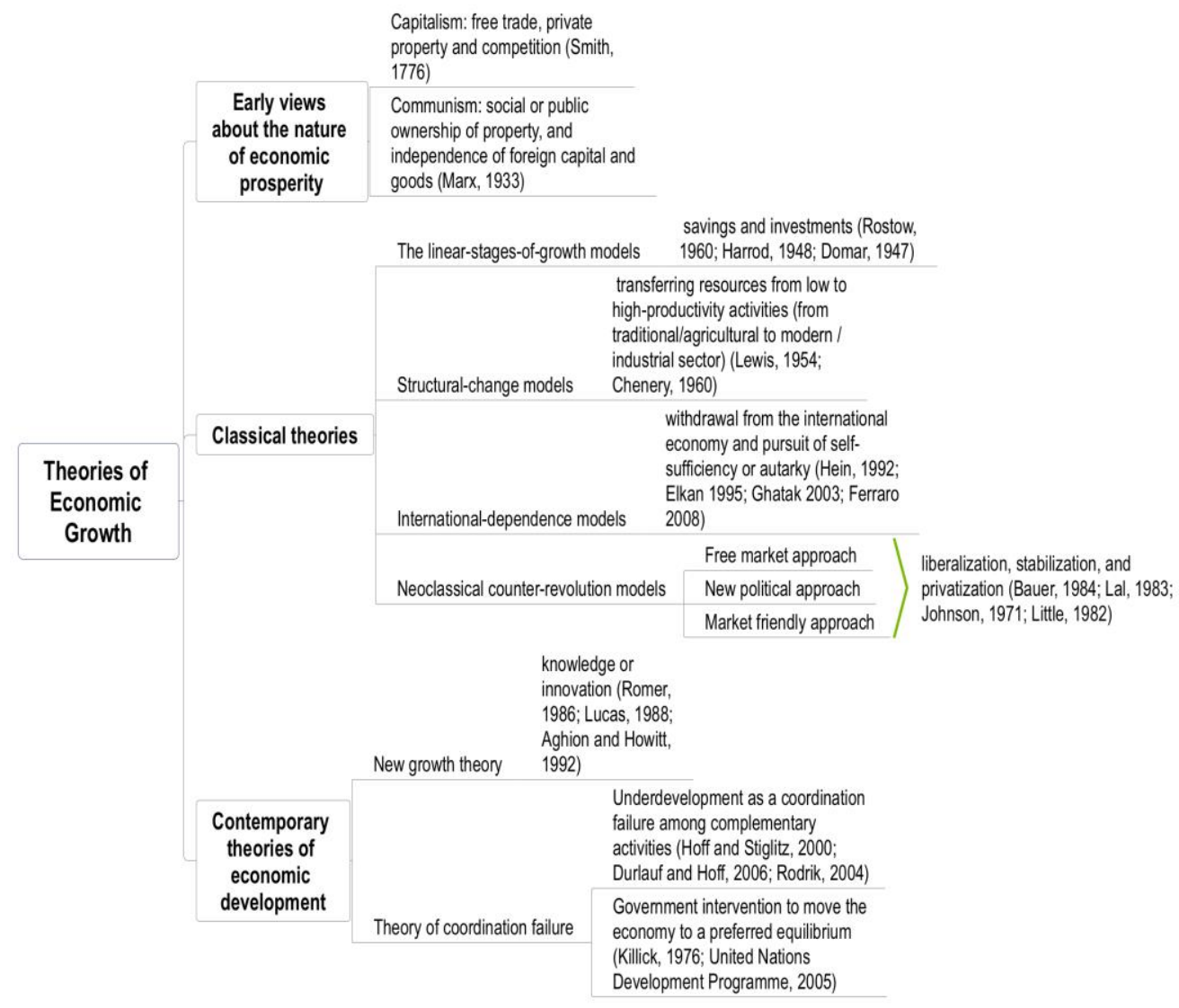

The emphasis of the theoretical and methodological basis preparation of research is based on the following goal-setting of any trajectory of socio-economic development of complex hierarchical systems: growth (or positive dynamics of GDP for ex.) (or gross income per capita); improvement in quality of life; sustainable (balanced, inclusive) development and the Millennium Development Goals (MDGs).

The concepts, methods and theories of ecological economics have influenced the 'green' economy policy proposal focused on such possible solutions as renewable energy, sustainable waste management, regenerative and sustainable cities and so on. The need for a Keynesian push for a green, smart and creative economy after the recent crisis was identified by the United Nations as early as 2009. A range of alternative paradigms and methods, however, were introduced much earlier: multicriteria decision aid in the 1960th, material flow analysis in the early 1970th, non- 
linear dynamics in the 1970th, econometric input-output modelling in the 1980th, the theory of basic human values in the 1980s and alternative measures of progress in the 1990th.

These kinds of general Keynesian arguments can in principle be applied as much to 'brown' or non-environmental spending as to 'green'. But some proponents of environmental spending go further, arguing that green measures in a recession are better for short-term growth. They point out in particular that many environmental measures are labour-intensive, and so give greater employment growth per dollar spent than non-green measures.

Much environmental spending is for various kinds of construction and resource management activities (wind turbines, solar panels, agricultural and water management) which, because they are location-specific, are not susceptible to 'offshoring' in the manner of much manufacturing.

Figure 2. Dynamics of average share of the EU countries' value added in service, industry and agriculture, \% of GDP in 1967 - 2016

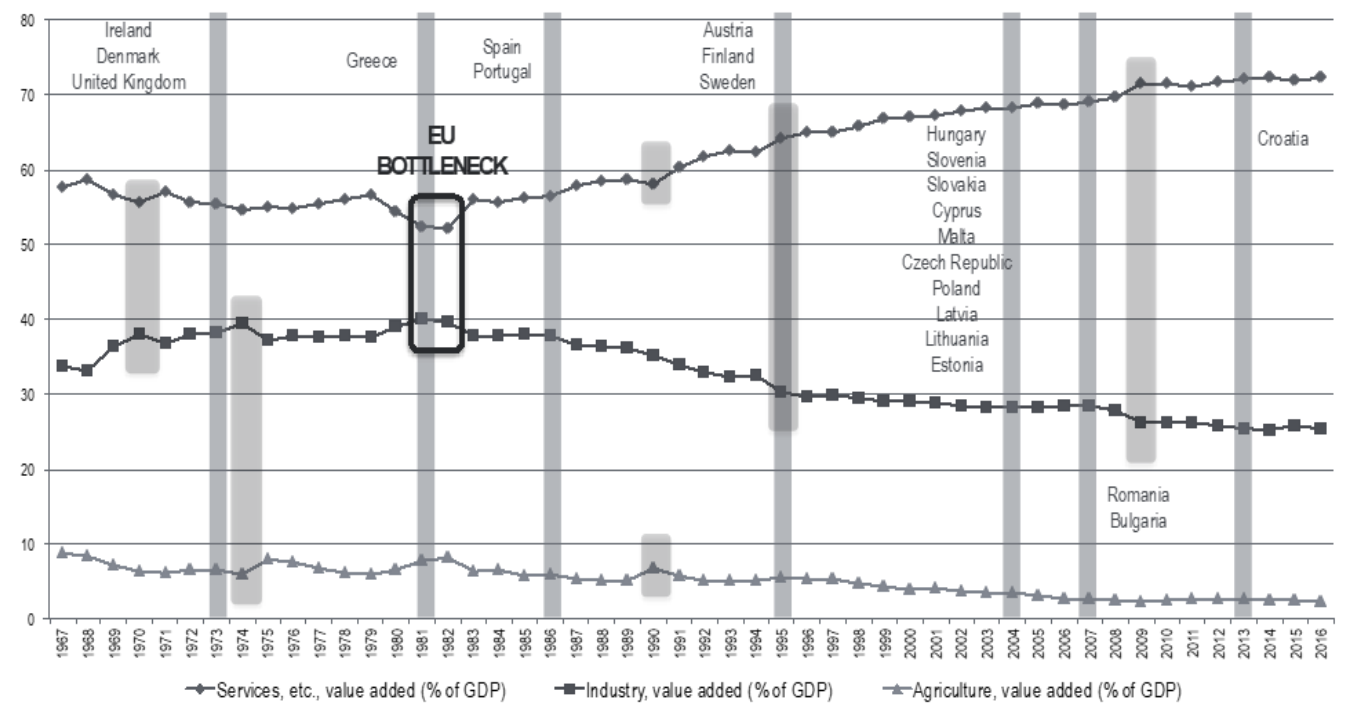

The scientific paradigm provides research for alternatives for measuring the growth of socio-economic systems and welfare of the population within the framework of the 'beyond GDP' concept in the impacts of the current challenges of economic development and increasing competitive pressure from the countries of Asia and the US.

After the cross-over of the economic 'bottleneck' of the EU countries in 1981-1982 (Fig. 2), structural transformations in the economy began - the share of industry in the structure of value added began to decline rapidly. The econometric analysis of 
the dynamics of value added in the structure of GDP made by industry provides clearly identifying of the three main stages of an almost twofold decrease from $40 \%$ in 1982 down to $22 \%$ in 2016 :

$\checkmark$ the first stage (1983 - 1995) - the entrance into the EU next countries as Spain, Portugal, Austria, Finland and Sweden provided significant advantages in the development of high-tech sector (financial incentive frameworks) through the formation of a high-tech the EU contour from Scandinavian countries (Ericsson and Nokia - past leaders of the world market of high technologies);

$\checkmark$ the second stage (1995-2008) was characterized with more linear increase in the service segment with a parallel decrease of the industrial sector in the structure of value added; it should be noted that at the same time the driver of human potential intensified due to a significant increase in the qualification level of the indigenous population because a significant influx of low-skilled labor from the newer EU member states to the fourth and fifth expansion waves;

$\checkmark$ the third stage (2009 - present) consolidates the trend towards deindustrialization of the EU countries due to the forced involvement of human capital in the total factor productivity.

As a result of the analysis (Table 1), it is obvious that the countries, the youngest members of the EU have the largest share of value added in agriculture in the limits from $3.8 \%$ to $6.1 \%$, which on average is $4.8 \%$.

Table 1. Cluster analyses of the average share of value added in the EU agriculture and Russia, \% of GDP in 2007 - 2016

\begin{tabular}{ccccc}
\hline \multicolumn{1}{c}{} & & & & \\
\hline $1,2 \%$ & $2,5 \%$ & $3,8 \%$ & $4,6 \%$ & \\
Sweden & Finland & Hungary & Croatia & Bulgaria \\
Germany & Italy & Lithuania & Russian Federation & Romania \\
Austria & Portugal & Greece & & \\
Denmark & Spain & Latvia & & \\
France & Slovenia & Slovak Republic & \\
Netherlands & Czech Republic & Estonia & \\
United Kingdom & Cyprus & & \\
Luxembourg & Poland & & \\
Ireland & & & \\
Belgium & & & \\
Malta & & & \\
\hline
\end{tabular}

The presented results testify either the peculiarities of the structure of the national economies that were included in the EU in 2004, 2007 and 2013, or the consolidation of the Uniform Agricultural Policy, which provides the maintenance of agricultural producers and structural reorganization, raising its productivity and efficiency within the three-tier model of the European cooperation (primary, regional and national sectoral cooperatives. The importance of the neophytes of European 
integration was reduced to the role of a raw material appendage in the EU framework with clearly defined quotas.

This led to appearance of the requirements of the Eastern Europe countries to adopt legislation that should prohibit companies from supplying goods of "double quality", i.e. to admit unacceptable that the products of the same brand with the same name and in identical packaging differ in the quality, depending on the EU countries where they are sold.

Moreover, these and similar procedures obstacle the implementation of the "green" economy principles placing a significant part of the potential of post-industrial development in knowingly losing conditions (Table 2).

Table 2. Cluster analyses of the average share of value added in the EU services and Russia, \% of GDP in 2007 - 2016

\begin{tabular}{ccccc}
\hline $71 \%$ & $66,1 \%$ & $78,4 \%$ & $67,4 \%$ & $59,9 \%$ \\
Sweden & Finland & Denmark & Ireland & Czech Republic \\
Germany & Slovenia & France & & Slovak Republic \\
Austria & Hungary & Portugal & & Romania \\
Italy & Croatia & Netherlands & & Russian Federation \\
Spain & Lithuania & United Kingdom & & \\
Latvia & Bulgaria & Luxembourg & & \\
& Poland & Belgium & & \\
& Estonia & Greece & & \\
& & Malta & & \\
& & Cyprus & & \\
\hline
\end{tabular}

The analysis confirms the desire of the EU countries to ensure balanced socioeconomic development, which is formed outside the material production sector - the sphere of services. It should be noted that the core of the EU countries maintained a tendency to increase the share of services in the structure of value added by going through the "bottleneck" in 1981-1983 for the past 37 years. This is the period of the minimum contribution of services to value added, which over time has only increased rapidly. Despite the shift in Brussels' emphasis on non-material production, the decisions to reduce the influence of the share of industrial production were not spontaneous. And if it is not more but the same size there were unequivocally compensated by increasing in the value of total factor productivity and / or growth in the service sector.

Presented trend indicates hidden protectionism (Table 3), which can not be regarded as an exceptionally negative phenomenon. In the face of increasing global competition, finding new sources of growth, the EU countries are striving to provide a long-term competitive advantage, shifting the center of economic gravity into the sphere of intangible production. The analysis of the dynamics of value added in the industry of the EU countries indicates a clearly expressed innovative character and 
significant deindustrialization in the classical sense. Particular importance is taken with the number of adopted initiatives in selected industries, such as steel, biotechnology and chemical production.

Table 3. Cluster analyses of the average share of value added in the EU industry and Russia, \% of GDP in 2007 - 2016

\begin{tabular}{ccccc}
\hline $29,5 \%$ & $23,9 \%$ & $17,7 \%$ & $31,3 \%$ & $35,4 \%$ \\
\hline Sweden & Denmark & France & Ireland & Czech Republic \\
\hline Finland & Italy & United Kingdom & & Slovak Republic \\
Germany & Portugal & Luxembourg & Romania \\
\hline Austria & Netherlands & Greece & Poland \\
Slovenia & Spain & Malta & Russian Federation \\
Hungary & Belgium & Cyprus & \\
Croatia & Latvia & & \\
Lithuania & & & \\
Bulgaria & & & \\
Estonia & & & \\
\hline
\end{tabular}

One of the most effective forms of EU industrial policy today is the creation of innovative clusters, which are $50.3 \%$ of small and medium-sized businesses and provide $3 / 4$ of the EU's exports (sales of high-tech equipment).

Table 4. Cluster analyses of the average GDP growth in the EU countries and Russia in $2000-2016, \%$

\begin{tabular}{ccccc}
\hline $1,2 \%$ & $0 \%$ & $3,1 \%$ & $4,2 \%$ & $1,9 \%$ \\
Sweden & Italy & Luxembourg & Ireland & Lithuania \\
Finland & Portugal & Malta & & Latvia \\
Germany & Spain & Bulgaria & Russian Federation \\
Austria & Croatia & Slovak Republic & \\
Denmark & Greece & Romania & \\
France & Cyprus & Poland & \\
Netherlands & & & \\
Slovenia & & & \\
United Kingdom & & \\
Hungary & & \\
Belgium & & & \\
Czech Republic & & & \\
\hline
\end{tabular}

Following the Action Program for Growth and Employment, the EU Commission adopted the updated Lisbon strategy that provides accelerated transition to higher technological structures, leveling a clear gradation not only between them but also the basic sectors of the economic system by Implementation of 7 Initiatives of the EU, five of which directly provide the formation of additional competitive advantages for the EU countries in the areas of high technology and post-industrial model of development. 
Figure 3. Triad of the EU countries' falls in the GDP growth in $1967-2016$

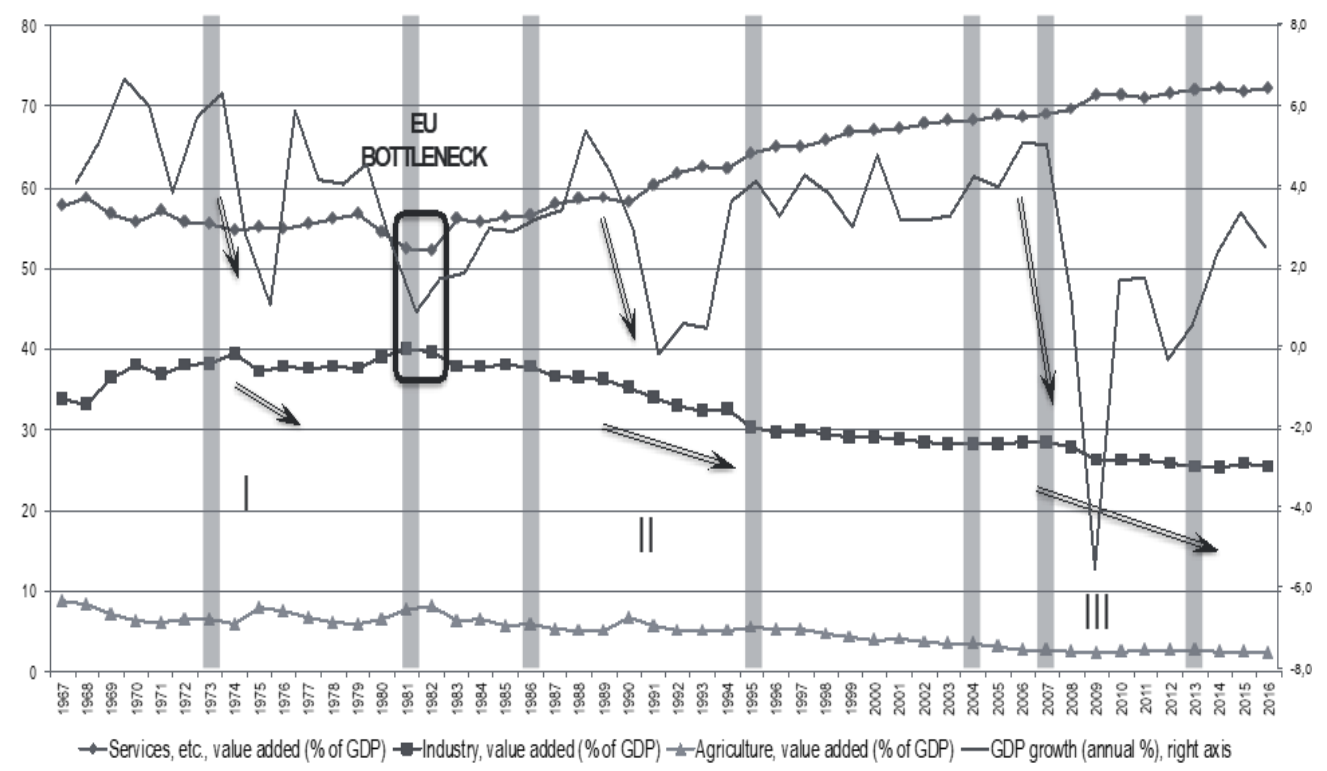

Current facts argue that the same objects mapped from one category to another, while maintaining their innate properties, conserve values in accordance to function. Thus, entropy accounting design is where form follows "entropy efficiencies" identified with the categories of production, consumption and capital accumulation. The economic domain (economic) is conceptualized as a proper subset of, and thus fully integrated in, the social-demographic domain (social), which, in turn, is a proper subset, and fully integrated in, the ecological domain (environment). Each domain is represented by the statistical datasets describing the quantities, qualities, and spatial distribution where relevant, of fixed, and circulating values and capital: economic capital $\rightarrow$ human/social capital $\rightarrow$ natural capital.

Cluster analysis of GDP dynamics for the period from 2000 to 2016 (table 4) shows that the drivers of the EU economy development are still in a state of recession, which is confirmed by a moderate growth rate of $1.2 \%$ on average. Moreover, it should be noted that the countries that joined the EU in the 5th and 6th wave of expansion demonstrate stable economic growth due to the lack of deep integration in the territorial and sectoral complex of the EU core countries. The presented analysis argues and empirically confirms the following theses (Figure 3):

$\checkmark$ since 1967, the EU countries have actively pursued a policy of deindustrialization, increasing the total factor productivity of the industry simultaneously concentrating industrial potential in the countries of the technological core of the EU and leveling the boundaries between high-tech production and the high-tech services; 
$\checkmark$ during the reviewed period, there were three triggers (I, II, III) that had a significant impact on the economic growth rates, which statistically confirm the significant correlation between the GDP dynamics and the value added of the industrial sector despite the exceeding of the growth rate in the service;

$\checkmark$ the presented results of the analysis testify the prospect of detachment of the sphere of non-material production from the real sector of the economy in the EU countries, which on the one hand may indicate the tendency of the fictitious economy of the postindustrial complex, which in reality is supported solely by material production, and on the other hand, green economy, which only in the long-term period has a significant impact on the growth rates of socio-economic system only on the basis of the full implementation of its basic principles in each of the stages of global value chains.

The 2016 Global Green Economy Index is being published as the United Nations General Assembly (UNGA) and Climate Week in New York City take place. As many nations will ratify their commitments to the recent climate agreement from the COP21 this week, attention must now turn to implementation. Some select findings from this 5 th edition of the GGEI include:

$\checkmark$ Sweden is again the top performing country in the 2016 GGEI, followed by the other "Nordics" and Switzerland, Germany, and Austria. Amidst these strong results, the GGEI identified areas where these countries can improve their green performance further. These opportunities - focused around innovation, green branding and carbon efficiency - could propel their national green performance forward even more in the future;

$\checkmark \quad$ like in 2014, Copenhagen is the top green city, followed by Stockholm and Oslo in the Europe. This new GGEI only collected perception values for green cities as lack of data availability continues to impede our efforts to develop a comprehensive green city performance index. Given the significant role of cities in the global green economy, city-level data development is an urgent priority;

$\checkmark$ while many European Union members perform near the top of this GGEI edition, others including the Czech Republic, Estonia, Poland, Romania and Slovakia rank near the bottom. These results are worrisome and suggest uneven national green performance across the EU;

$\checkmark$ the United Kingdom's GGEI performance continues to lag behind its EU peers, ranking 25 th of the 80 countries covered. While the UK does very well on both the perception and performance side of the Markets and Investment dimension, inconsistent policies supporting renewable energy and green growth continue to hurt the UK on other parts of the GGEI.

The final stage of the presentation is the clustering of the EU countries that allows to identify the target S-shape trajectory of achieving green growth (Figure 4). The first 
cluster is characterized by weak rates of economic growth and the implementation of green growth projects. The second one indicates the cluster of countries with positive economic dynamics, but also its weak ecological compatibility. The third cluster combines positive dynamics of GDP growth and the implementation of the principles of a green economy.

Figure 4. The cluster analyse of relationship between the average annual level of GDP dynamics (\%, X-axis) - from 2010 up to 2015 and the average Global Green Economy Index (GGEI) - 2014 and 2016 in the EU countries (points, Y-axis)

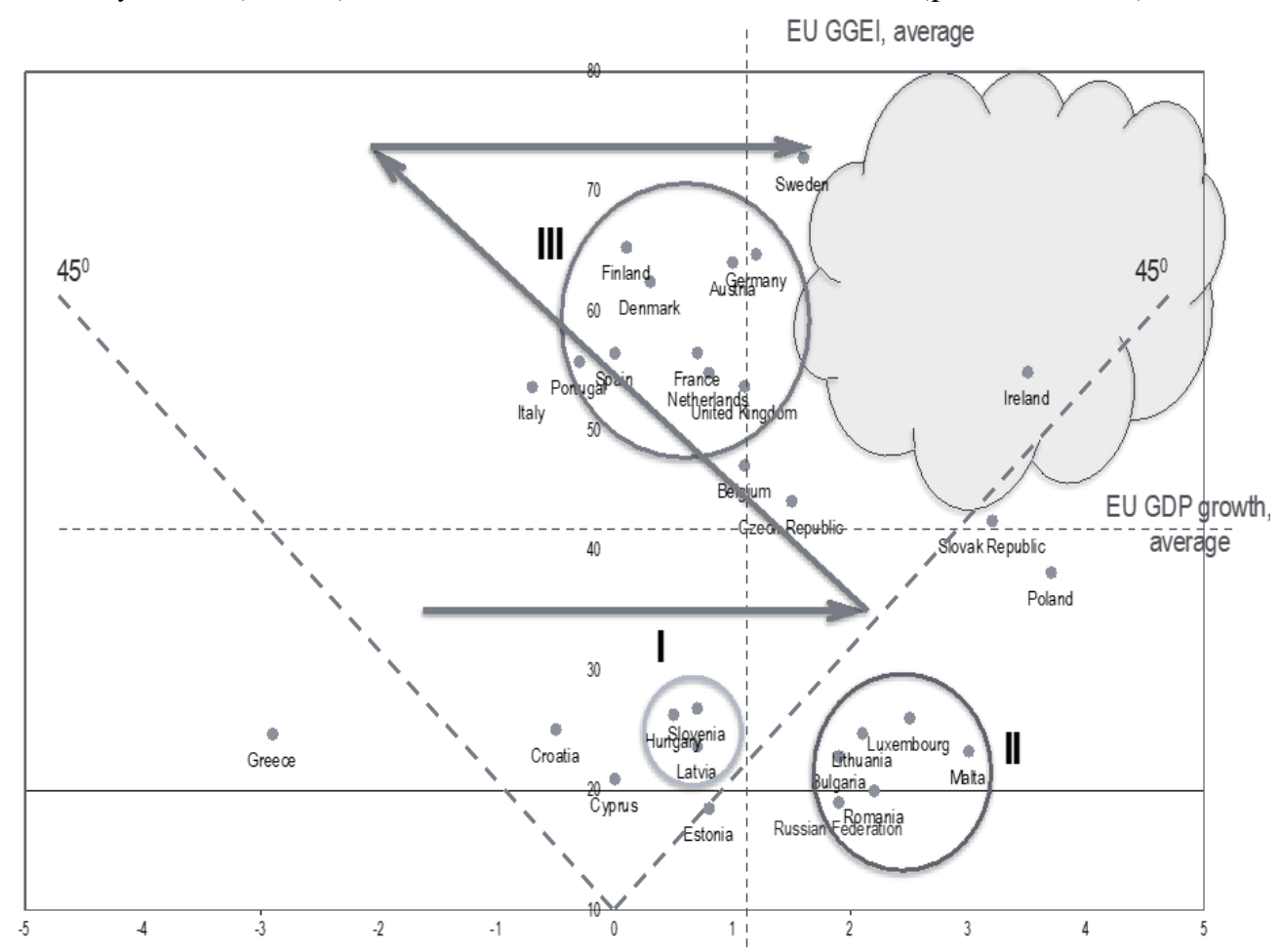

For the EU countries within the framework of an additional system of coordinates along the EU GDP growth, average and EU GGEI, average, the presented cloud is a lighthouse for ecological economic growth.

In conclusion, it should be said that the presented empirical data on trends, factors and prospects for economic growth in the EU countries, as well as conducted economic and mathematical analysis allows us to identify the main threats to future economic growth, regardless of its typology:

- changes in the real exchange rate affecting competitiveness;

- cyclical fluctuations in national output and external trade;

- financial instability e.g. unsustainable credit boom and fall in savings;

- volatility in world prices for essential imports and key exports; 
- political instability / military conflicts;

- natural disasters and other external supply shocks;

- unexpected breakthroughs in the state of technology.

\section{Conclusion}

The nature of economic growth in the coming decades will have to be fundamentally different from the resource-intensive growth of the past and it will need to be assessed against the criterion of whether it satisfies demands for well-being for a larger global population while adjusting to the tightening environmental constraints. A number of structural factors underlying the EU countries growth picture need to be addressed by the international community in any proposals about a green and inclusive economy.

Redesigning state macroeconomic policies of Russia is the key of focusing on a new approach to economic growth. In fact, Russian macroeconomic policies not only affect the dynamics of economic activity, income distribution, investment and employment, but they can also bring about the required structural economy-wide changes associated with a green economy transformation and become a problematic field of future research.

\section{References:}

Beck, U. 2016. The Metamorphosis of the World: How Climate Change is Transforming Our Concept of the World. Polity Press, 239.

Bell, D.A. 2016. The China Model: Political Meritocracy and the Limits of Democracy. Princeton University Press, 360.

Boulding, K. Income or wealth. Review of Economic Studies, 17, 77-86.

Cooke, Ph. 2015. Green governance and green clusters: Regional and national policies for the climate change challenge of Central and Eastern Europe. Journal of Open Innovation: Technology, Market, and Complexity Technology, Market, and Complexity.

Dual Citizen LLC, 2016. The Global Green Economy Index. Washington, DC., 127.

Eisenstadt, S.N. 2002. Multiple Modernities, Routledge, 282.

Engel, D, and Kammen, D.M. 2009. Green Jobs and the Clean Energy Economy. Copenhagen, Copenhagen Climate Council.

Georgescu-Roegen, N. The entropy law and the economic process. Harvard University Press, Cambridge, MA.

Giddens, A. 2016. Introduction to Sociology (Seagull Tenth Edition), W.W. Norton \& Company, 816.

Green New Deal Group. 2008. A Green New Deal. London: New Economics Foundation.

Hajer, M. 2007. The politics of environmental discourse. Ecological modernization and the policy process. Clarendon Press, London.

He, Ch. 2001. China Modernization Report.

Held, D. 2002. Governing Globalization: Power, Authority and Global Governance. Polity Press, 386. 
Huber, J. 2008. Technological environmental innovations (TEIs) in a chain-analytical and lifecycle-analytical perspective. Journal of Cleaner Production, 16(18).

Huntington, S.P. 1996. The Clash of Civilizations and the Remaking of World Order. New York, Simon and Schuster.

Inglehart, R. 2005. Modernization, Cultural Change, and Democracy: The Human Development Sequence, Cambridge University Press, 344.

Krugman, P. 2016. Paul Krugman Commencement Speech. https://simons-rock.edu/studentsfamilies/commencement/commencement-2016/paul-krugman-speech.php

Lerner, D., Lyle, M.N. and Wilbur, L.S. 1977. Communication Research: A Half-Century Appraisal. University Press of Hawaii.

Lyotard, J.F. 1984. The Postmodern Condition: A Report on Knowledge. Theory and History of Literature, 10, University of Minnesota Press, 144.

Martinez-Alier, J. 1987. Ecological economics: Energy, environment, and society. Basil Blackwell, Oxford.

Medvedeva, L.N., Kozenko, Y.K. and Komarova, P.O. 2016. Environment Quality Management in Green Cities. European Research Studies Journal, 19(2), 34-45.

Parsons, T. 1979. Religious and Economic Symbolism in the Western World. Sociological Inquiry, 49(1), 1 - 48.

Pearce, D., Markandya, A., Barbier, E. 1989. The Blueprint for a Green Economy. London, Great Britain, 192.

Pociovalisteanu, M.D., Thalassinos, I.E. 2008. The beginning and some national particularities of liberalism. Metalurgia International, 13(2), Special Issue, 172-177.

Stiglitz, J.E., Greenwald, B.C. 2015. Creating a learning society: A new approach to growth, development, and social progress. Columbia, Columbia University Press.

Thalassinos, I.E. and Pociovalisteanu, M.D. 2009. The Structural Funds and the Economic and Social Cohesion Process. Annals-Economy Series 1, 313-330.

Thalassinos, I.E. 2007. Trade Regionalization, Exchange Rate Policies and EU-US Economic Cooperation. European Research Studies Journal, 10(1-2), 111-118.

The Great Divide, 2015. Unequal Societies and What We Can Do About Them. W.W. Norton Company.

The Growth Report, 2008. Strategies for Sustained Growth and Inclusive Development. Washington, DC.

Tiryakian, E.A. 1970. Theoretical Sociology: Perspectives and Developments. AppletonCentury-Crofts, Educational Division, 538.

UN. 2015. The Millennium Development Goals Report. United Nations, NY, 76.

UNEP. 2010. Green Economy Developing Countries Success Stories. UNEP, Geneva.

Wallerstein, I. 2014. Overcoming Global Inequalities. Political Economy of the WorldSystem Annuals, Routledge, 239.

Walt, W.R. 1975. How it all Began: Origins of the Modern Economy, New York, McGrawHill Book Company, 264.

Zapf, W. 1971. Social indicators: Prospects for social accounting systems?, Goethe Universitat, 42. 